\title{
Hero, Champion of Social Justice, Benign Friend: Theodore Roosevelt in American Memory
}

\section{Katy Hull}

\section{(2) OpenEdition}

\section{Journals}

Electronic version

URL: https://journals.openedition.org/ejas/13403

DOI: 10.4000/ejas.13403

ISSN: 1991-9336

Publisher

European Association for American Studies

\section{Electronic reference}

Katy Hull, "Hero, Champion of Social Justice, Benign Friend: Theodore Roosevelt in American Memory", European journal of American studies [Online], 13-2 | 2018, Online since 05 October 2018, connection on 08 July 2021. URL: http://journals.openedition.org/ejas/13403 ; DOI: https://doi.org/ 10.4000/ejas. 13403

This text was automatically generated on 8 July 2021.

Creative Commons License 


\title{
Hero, Champion of Social Justice, Benign Friend: Theodore Roosevelt in American Memory
}

\author{
Katy Hull
}

\section{History and Memory}

Our memories are a representation of the past and a production of the present. Maurice Halbwachs, the French sociologist whose work is foundational for all theorists of memory, argues that memories are socially constructed: collective memories are formed through the interaction of groups, whether organized by family, religion, or class; and each group reconstructs a version of the past that is adapted according to "contemporary exigencies." Halbwach's theories have led some scholars to ascribe the production of memories primarily to an "evanescent present." ${ }^{2}$ But others have challenged this interpretation. According to the sociologist Barry Schwartz, "[e]very society...displays, and perhaps even requires, a minimal sense of continuity with the past." Collective memories, according to Schwartz's interpretation, are built around a central kernel; successive generations may revise, but will never wholly obliterate, past conceptions. ${ }^{3}$

2 Following Schwartz's understanding of the function of memory in society, this article demonstrates that there are significant continuities in American memories of Theodore Roosevelt. In particular, it identifies three recurring motifs in how Americans remember their twenty-sixth president: as a heroic and intensely masculine leader; as a champion of social justice; and as a benign figure. None of these memories has gone uncontested. Leftist scholars and activists have been at the forefront of efforts to pierce dominant memories of Roosevelt. These alternative memories, or "counter-memories," have challenged but never unseated persistent tropes. ${ }^{4}$

3 To date, scholars have analyzed memories of Roosevelt in discrete sphereshistoriography, film, or foreign policy, for example-or over narrow time periods. ${ }^{5} \mathrm{By}$ 
analyzing memories of Roosevelt in popular culture, politics, and scholarship from his death to the present day, this article draws broader conclusions. It argues that the interplay between memories and counter-memories of Roosevelt is indicative of the relative discursive power of various social groups. The continued resonance of memories of Roosevelt as a hero, champion of social justice, and benign friend demonstrates that while not immune to periods of national self-reflection, many Americans revert reflexively to historical memories that reaffirm their own stature, capacity for progress, and good intentions, even at the expense of moving toward a truer, and more usable, understanding of the past.

\section{The Roosevelt Image in His Lifetime}

As a master manipulator of his own reputation, Theodore Roosevelt cultivated each of the three images-the masculine leader, the benign figure, and the champion of social justice-assiduously, recognizing that all were essential for political success in the modern age. TR crafted himself as an embodiment of masculinity at the early stage of his career, in response to the rough and tumble of politics in Albany, where he was labeled "Jane-Dandy." His escape to the Dakotas, following the death of his mother and wife in 1884, was not an escape from politics; rather, it was central to the reshaping of his political image. ${ }^{7}$ Embracing modern media, Roosevelt communicated his ranchman image to the public, posing for photographs in his tailor-made buckskin costume, and writing articles on his exploits for Century magazine. ${ }^{8}$ Most notably, Roosevelt used his leadership of the First Volunteer Cavalry in Cuba in 1898 to cement his reputation as a masculine hero. He went into battle flanked by his favorite journalists, and complemented their reports with his own version of events-The Rough Riderspublished in 1899. ${ }^{9}$

5 Roosevelt also used his personal warmth to great political effect: he charmed his audiences with what his biographer, Edmund Morris, describes as his "famous electricity," and disarmed his opponents with unremitting exuberance. ${ }^{10}$ The president took journalists on family trips to Sagamore Hill, feeding reports of a rambunctious clan, headed by their gentle giant of a father. ${ }^{11}$ Perhaps the most enduring rendition of the benign Roosevelt is the Teddy Bear myth, which originates from a 1902 report that the president refused to shoot a wounded bear cub whilst on a hunting trip in Mississippi. Roosevelt, the man who shot and killed with almost unparalleled ardor, became the namesake for the most-loved children's toy. ${ }^{12}$

6 Finally, especially toward the end of his career, Roosevelt consciously crafted an image of himself as a champion of those oppressed by a system of unfettered capitalism. In Osawatomie, Kansas, in 1910, TR issued a call for greater government intervention in the economy to ensure a fairer system for all. ${ }^{13}$ His leadership of the progressive wing of the Republican Party after 1910, and his formation of a third party in 1912, provided him with an opportunity to cast himself as a savior of the people. ${ }^{14}$

The criticisms that Roosevelt's detractors leveled against him during his lifetime would likewise form the basis for counter-memories that emerged after his death. Critics speared Roosevelt for his aggression, chauvinism, and egotism. Mark Twain wrote biting indictments of the consequences of Roosevelt's imperialism for the "person sitting in the darkness." ${ }^{15}$ Responding to TR's tirades against "race suicide," the literary critic William Dean Howells wondered about the consequences of high birth rates on 
the working class's grocery and gas bills. ${ }^{16}$ And implying that Roosevelt's political passions were motivated by raw ambition, unfriendly newspapers tracked the number of times he used "I" in his speeches. ${ }^{17}$

8 Dominant themes in Theodore Roosevelt's image and counter-image were established before he died. While subsequent iterations evolved in the context of changing social conditions, both admirers and critics would build upon a familiar core of memories, consolidated in these early years.

\section{Hagiographic Post-Mortems}

9 The adage "everyone loves you when you are dead" rang true for Theodore Roosevelt, and his passing, in 1919, ushered in a decade of hagiography. Critics of TR during his lifetime became friends in his death. As Washington correspondent for the New York Times from 1898 to 1907, Charles Willis Thompson had been critical of many of TR's policies. ${ }^{18}$ But after his death, Thompson wrote of "the magic" of the president's personality, "his large, joyous, and generous soul." ${ }^{19}$ In a lengthy article published on the ten year anniversary of TR's death, Thompson claimed that Roosevelt's "place in history" was assured by his fighting character, his keen sense of social justice, and his patriotism. ${ }^{20}$

In his post-mortem contributions, Thompson echoed Roosevelt's own gendered discourse.$^{21} \mathrm{He}$ argued that the president's male detractors had been "persons of a feminine cast." ${ }^{22}$ Roosevelt's calls for preparedness after 1915 were, according to Thompson, evidence of his hard-edged realism in the face of the "mushy school" of pacifists who threatened to "enervate manhood." ${ }^{23}$ The accompanying photographs for Thompson's 1929 article depicted Roosevelt in dynamic poses: on horseback in Cuba; and standing on the campaign stump, his fist raised. In the only seated image to appear in the article, Roosevelt, the young police commissioner, was still conspicuously energetic; in contrast to his aging colleagues, who sat at ease, he pressed his hand against his armrest, as if ready to spring up at a moment's notice. ${ }^{24}$

11 The hagiographic tone of Roosevelt scholarship in the 1920s was due in part to Roosevelt's own efforts, and those of his well-connected family members and friends, to control his historical legacy. ${ }^{25}$ Roosevelt's autobiography and an approved selection of his letters became the principal documentary sources for a first generation of historians. ${ }^{26}$ Hermann Hagedorn was a friend of Roosevelt in his lifetime and a founder of the Roosevelt Memorial Association (RMA) after his death. Hagedorn headed up the RMA's efforts to perpetuate memories of Roosevelt among young audiences; his Boys' Life of Theodore Roosevelt, first published in 1918, taught a generation of school children that Roosevelt was the "the doer of heroic things." 27

12 Also among the admirers was the British popular historian Lord Charnwood, whose 1923 biography was widely read in the United States. Charnwood expressed a "boyish hero-worship" for Roosevelt the polymath, the trustbuster, and the arbitrator of industrial tensions..$^{28}$ Charnwood was particularly enamored by the methods that Roosevelt pursued in the anthracite strike and Northern Securities case, perpetuating TR's image as a champion of social justice. In both instances, Roosevelt had taken unprecedented action to assert the federal government as an intermediary between 
"the people" and concentrations of wealth, Charnwood wrote, demonstrating that the president could act as a "reconciler" of "social and industrial strife." ${ }^{29}$

Glowing written portraits of Roosevelt had their physical counterpart in the efforts of the RMA to secure a monument to the president in a prime position on the Washington Mall in the mid 1920s. In its sheer proximity to the Washington and Lincoln memorials, the RMA's planned memorial was a clear statement of its members' belief that Roosevelt was "one of the three greatest American leaders." But congressional objections to the proposals forced the RMA to purchase Analostan (later Roosevelt) Island-a tract of land in the Potomac-in 1931, for a more discreet celebration of Roosevelt as a conservationist. ${ }^{30}$ Congress's pushback on the RMA's proposals suggests that even during a period of intense Roosevelt worship, a portrait of him as one of the greatest American leaders was not uncontested.

It was left to Gutzon Borglum, a private citizen and a supporter of the 1912 Progressive Party, to give Roosevelt a permanent place beside Washington, Jefferson, and Lincoln at Mount Rushmore. In 1927, Calvin Coolidge ascended the site on horseback, dressed in cowboy attire, to preside over the monument's dedication ceremony. Coolidge asserted that Roosevelt was worthy of inclusion in the pantheon of great presidents. Avoiding references to TR the trust-buster, Coolidge claimed that Roosevelt had enhanced "economic freedom" and, by building the Panama Canal, had strengthened the ties between East and West. The dedication ceremony marked the beginning of a twelveyear construction process. Claiming full support of all South Dakotans for the creation of a new "national shrine," Coolidge made no mention of the Sioux, who considered the Black Hills of South Dakota to be sacred space. ${ }^{31}$

What explains Roosevelt hagiography in the decade following his death, other than the immediate flush of affection that societies tend to bestow upon their recently departed? World War I and its aftermath witnessed a rapid waning of the progressive movement, with the erosion of civil liberties, violent strikes, and a crippling Red Scare. ${ }^{32}$ By the mid-1920s, corporations were in the ascendancy and successive Republic administrations were both powerless and unmotivated to hold private power in check. ${ }^{33}$ In this context, Roosevelt's admirers expressed nostalgia for a time when a Republican leader had embraced the presidency as an opportunity to mediate between conflicting interests and cultivate countervailing forces to control corporate power. Meanwhile, the horrors of mechanized warfare, and the routinization of the mechanized workplace, contributed to a wistfulness for unbounded masculine energies, as embodied in TR. The decade following Roosevelt's death thus cemented images of TR as a champion of social justice and a heroic, masculine leader.

\section{Voices of Discontent}

Disillusionment in the 1920s tended to boost Roosevelt's reputation, but it could also provoke disgust with the society that worshipped him. Writing in the Smart Set, the satirical magazine of the New York elite, Henry Louis Mencken used memories of TR to impugn mass culture as facile and naïve. For Mencken, Roosevelt's defects "were the defects of his race and time," and the flood of eulogies following his death was evidence of the weak intellect of the average American. ${ }^{34}$ Less than two years after the end of World War I, Mencken made a provocative comparison between Roosevelt and Kaiser Wilhelm: 
Both roared for doughty armies, eternally prepared ... Both delighted in the armed pursuit of the lower fauna ... If, in fact, there was any difference between them, it was all in favor of Wilhelm. For one thing, he made very much fewer speeches. ${ }^{35}$

For both Mencken and the Pulitzer Prize winning biographer, Henry Pringle, there was more showmanship than substance to Roosevelt's reputation as a social progressive. Writing in 1931, Pringle argued that TR's leadership of the Progressives was no more than a cynical bid for political power, taken up and abandoned in the same cavalier fashion. ${ }^{36}$ As one historian subsequently noted, Pringle even attacked Roosevelt's "successful accomplishments ... by making them either secondary products of an insatiable urge for power or the fortuitous result of an adolescent impulse." ${ }^{37}$

Although Theodore Roosevelt was the direct target, these authors took broader aim at the society that enabled his political successes and worshiped him in absentia. Their formula-known as debunking-was an expression of pessimism about American culture and society in the 1920 s and early depression years. ${ }^{38}$ Writing during the onset of the Great Depression, Pringle acknowledged his disillusionment with the milieu that allowed leaders like Roosevelt to thrive. "Politics is fundamentally a hysterical calling," Pringle wrote. "Unless it is finance, there is no activity so beset with rumors and alarms." ${ }^{39}$ Theodore Roosevelt was a cipher for Pringle's and Mencken's more thorough discontent with American democracy.

Even as they aimed to topple images of Roosevelt as a masculine ideal and champion of social justice, the debunkers contributed to the third major facet of TR memory in their construction of Roosevelt as a benign creature. Mencken noted that "the sweet went with the bitter. He had all the virtues of the fat and complacent burgher." ${ }^{40}$ Pringle's Roosevelt was more ridiculous than dangerous. To underline these characteristics, Pringle weighted his biography toward the less substantive sides of the president's achievements, allotting more attention to TR's attempts to reform spelling than to his efforts to ensure safety in the food and drug industries. ${ }^{41}$

Mencken's and Pringle's interpretations functioned as a form of counter-memory, existing alongside persistent images of Theodore Roosevelt as an effective leader. Debunking appealed to an intellectual elite, which viewed itself as more sophisticated, and more critical, than the average American. But cynical views, which prevailed as a frivolous decade reached its ignominious end, would soon lose their resonance. As Mencken's biographer, Fred Hobson, writes, while “the 1920s had been Mencken's decade ... the 1930s, grim and earnest, emphatically was not." ${ }^{42}$

\section{A New Roosevelt}

Conscious of the benefits of the Roosevelt name, Franklin Roosevelt drew liberally upon memories of his fifth cousin to bolster his own political standing. ${ }^{43}$ In 1927 at Mount Rushmore, Calvin Coolidge had avoided references to TR's progressive bent. Franklin Roosevelt molded memories of Roosevelt to suit opposing political purposes: his TR was a progressive pragmatist who had used the presidency as a "pulpit" to advance the interests of ordinary Americans. Campaigning in 1932, Franklin named Theodore as one of the four most interesting men in American history, and one of the few presidents who had successfully adapted his office in response to contemporary realities. ${ }^{44}$

Franklin's 1933 inauguration encouraged reflections in the "What Would Theodore Do?" genre. Writing in the New York Times, the historian Allan Nevins insisted that 
Theodore, like Franklin, would have reversed the policies of previous Republican administrations..$^{45}$ Even Pringle's own contribution to the genre functioned as a tacit acknowledgment that his 1931 biography had bordered upon caricature. In 1936, Pringle argued that "Theodore Roosevelt would never have tolerated starvation in a land of plenty," he would have bolstered federal government to control excessive concentrations of wealth, and he would have supported some measures to strengthen labor. There was perhaps no stronger testimony to the limited resonance of the debunkers' portrait than the willingness of Pringle himself to turn to Theodore Roosevelt as a model for what to do in times of unprecedented national suffering. ${ }^{46}$

In 1936, Franklin Roosevelt presided over the dedication ceremony for the Theodore Roosevelt Memorial Hall at the American Museum of Natural History in New York. Franklin's speech was peppered with words-such as "vital," "passion," and "pungent"-that evoked Theodore's exuberant masculinity. FDR honored TR as a leader with a "strong sense of social justice," missing no opportunity to indicate that, were he alive, the elder statesman would have endorsed the New Deal. ${ }^{47}$ Appointments of erstwhile TR associates, including the former Bull Moosers Harold Ickes and Donald Richberg, the Rough Rider Frank Knox, and Republican stalwart Henry Stimson, signaled that Franklin, like Theodore, was willing to cross party lines if it served the best interests of ordinary Americans. ${ }^{48}$

FDR enthusiastically supported funding for Mount Rushmore, enabling TR's likenessthe last to be completed-to emerge swiftly from the stone..$^{49}$ The 1939 unveiling of the Roosevelt carving was "by far the best attended of all the Rushmore dedications." In a combination of Lakota, English, and Indian sign language, William S. Hart, the veteran Western actor, chose the occasion to speak on behalf of the Sioux people. His call for justice fell on deaf ears: CBS turned off his microphone. ${ }^{50}$ Over the course of the 1930s, American Indian and women's rights activists had campaigned for a more inclusive vision of the nation at Mount Rushmore. Sioux chief Henry Standing Bear had called upon Borglum to include a carving of Crazy Horse in the pantheon of American heroes; Rose Arnold Powell had lobbied tirelessly for a place for Susan B. Anthony among the greats. But no changes were made to the original schema. ${ }^{51}$

There is no record of similar controversies accompanying contemporaneous tributes to TR in New York. William Mackay's murals in the Theodore Roosevelt Hall of the American Museum of Natural History opened to the public in 1936. In this unabashed celebration of TR as a naturalist and statesman, the president stood among Nubian lions, pored over engineering plans for the Panama Canal, discovered the River of Doubt, and presided over the signing of the Treaty of Portsmouth..$^{52}$ In October 1940, with war clouds on the horizon, Edith Roosevelt unveiled James Earle Fraser's bronze statue of her late husband at the museum's entrance..$^{53}$ Roosevelt, mounted on horseback, loomed large over an American Indian in traditional headdress and a halfclad African, who flanked him at either side. Expressing wistfulness for decisive leadership in a time of impending crisis, the New York Times editorialized:

[F]ew, passing the newly dedicated statue and noting the firm, up-tilted chin and eyes fixed on a far distance, will doubt that this leader of other days would have met present problems face-forward, with high courage and clear decision. ${ }^{54}$ The high visibility of public works leaves them open to interpretation and reinterpretation by multiple viewers. But, as John Bodnar argues, discursive power is unequally weighted toward those who are "most powerful in the social structure" and 
"influential in the discussion and construction of memory." ${ }^{55}$ Over the decades to come, some would criticize these memorials as symbols of chauvinism, arrogance, and imperialism. But many others would accept them as those who commissioned and created them intended: as a celebration of Theodore Roosevelt as an exemplary leader, an archetype of masculinity, and an American icon.

If the debunkers' Roosevelt lost salience over the course of the 1930s, one element-the image of the affable extrovert-endured. This portrait of Roosevelt had its popular expression in Joseph Kesselring's 1941 play Arsenic and Old Lace, which was made into a motion picture starring Cary Grant in 1944. In this play, Teddy Brewster was the unwitting accomplice to his murderous aunts. Suffering from a delusion that he was the twenty-sixth president, he appeared on stage at regular intervals, shouting "bully" and "[d]ee-lighted." ${ }^{56}$ According to John Gable, for a "great many Americans" in the 1940s, this "funny and crazy character...was the mirror image, only slightly distorted, of Teddy Roosevelt." ${ }^{57}$ By the early 1940s, Roosevelt was, temporarily at least, defanged.

\section{The Cold War Roosevelt}

The Cold War required activist leadership to confront communism abroad and head off its threat at home, and memories of Theodore Roosevelt adjusted to fill this role. Intimate portraits in the 1950s augmented previous conceptions of TR as an archetype of masculinity. Images of Roosevelt as a father contributed to the atmosphere of "domestic containment," endorsing a more active role for men in family life as an antidote to the supposedly enervating effects of mothers on their sons. ${ }^{58}$ In 1953 , the Theodore Roosevelt Association (TRA) opened up Sagamore Hill, the Roosevelt family home in Oyster Bay, to the public. Attracting 80,000 visitors in its first year, the home exposed the public to the details of Roosevelt family life. ${ }^{59}$ Hermann Hagedorn's The Roosevelt Family of Sagamore Hill was the Book-of-the-Month Club choice for August, $1954 .^{60}$ Here was a father never so weighed down by the responsibilities of his office that he could not afford time to wrestle, hike, and play with his offspring. ${ }^{61}$ Building upon previous images, crafted by Roosevelt himself, these domestic portraits functioned as a model of fatherhood in the 1950s, as psychologists called upon men to engage warmly in family life so as to rear socially-adjusted and heterosexual offspring. 62

Roosevelt's foreign and domestic policies also attracted renewed praise during the early Cold War. Writing in 1954 and 1961, respectively, the historians John Blum and William Harbaugh portrayed TR as a skilled practitioner of realpolitik, who embraced the responsibilities of global leadership and demonstrated genuine commitments to peace through his mediation of an end to the Russo-Japanese war. ${ }^{63}$ Both Blum and Harbaugh suggested that Roosevelt combined foreign policy activism with substantive domestic reforms. Reflecting on his policies toward capital and labor, Harbaugh argued that Roosevelt was the first president to:

concern himself with the ... the maldistribution of wealth, and the subversion of the democratic process by businessmen and their spokesmen in Congress ... and the first to encourage, however cautiously, the growth of countervailing labor unions. ${ }^{64}$

The notion that contemporary presidents might learn from TR's combination of foreign and domestic policy activism was implicit in Blum's and Harbaugh's work. Arthur Schlesinger was much more explicit in his belief that Roosevelt offered a valuable 
model for leadership in early Cold War America. In a treatise first published in 1949, Schlesinger cast Roosevelt as the embodiment of the "vital center"-a leader who shunned corporate dominance and socialism with equal vigor and injected dynamism into the Republican political tradition. In a theme that would become familiar to future historians, Schlesinger argued that by rejecting Roosevelt in 1912, the Republicans abandoned activist and compassionate politics in favor of laissez-faire complacency. ${ }^{65}$

As argued by the historian Kyle Cuordileone, Schlesinger's call for a virile form of political leadership had a profound effect on the political style of John F. Kennedy. ${ }^{66}$ Contemporaries observed similarities between Roosevelt and Kennedy, noting that the two were alike in their youth, their intellectual pedigrees, and their "adventurous" styles ${ }^{67}$ Kennedy's 1960 article in Sports Illustrated calling on American men to enhance their physical fitness bore eerie similarities to Roosevelt's calls for men to embrace the "strenuous life." ${ }^{88}$ Both Roosevelt and Kennedy were enamored with the concept of wars fought by elite, volunteer forces ${ }^{69}$ Moreover, Kennedy, like Roosevelt, used his family to emphasize his youthful vigor. As a recent commentator has observed, "who could look at John F. Kennedy, scrimmaging with his clan at Hyannis Port, and not be reminded of another young President, tussling with his kids"? ${ }^{70}$ Kennedy exploited the Roosevelt parallel to turn accusations of youthful inexperience to his own advantage, indicating that with youth came masculine energies befitting of a cold warrior.

In the Cold War atmosphere of earnest nationalism, images of Roosevelt as a bumbling character temporarily fell away. A 1958 issue of Time, coinciding with the centenary of Roosevelt's birth, represented the apogee of the Roosevelt revival: confronted by the threat of "foreign autocracy," Roosevelt had boldly embraced the "power of the U.S. government" and built up military forces to wield "a new kind of power-deterrence" on the global stage. ${ }^{71}$ The Time tribute made transparent an idea that ran through much contemporary scholarship and popular memory-making: Roosevelt was a man for the season.

\section{The New Left Counterattack}

On June 14, 1971 six young American Indians defaced James Earle Fraser's statue of Theodore Roosevelt outside the American Museum of Natural History, spray-painting "Return Alcatraz" and "Fascist Killer" at the base of the monument. ${ }^{72}$ These young people explained that they chose the Roosevelt memorial as the target for their protest because they considered it "racist"; "[i]f you've seen the statue," said a local organizer, "you could guess why." ${ }^{.3}$ Members of the American Indian Movement (AIM) also occupied Mount Rushmore on several occasions in the early 1970s. The historian Matthew Glass notes that while most Americans associated Mount Rushmore with a glorious history of American expansion, the activists associated each presidential carving "with a specific set of injustices." In 1970, AIM member Reuben Snake wrote that Roosevelt had "nationalized the park service by taking Indian land for White America's playground." 74

Equally visceral memories of Theodore Roosevelt prevailed for some African Americans in these years. According to scholars influenced by the Black Power movement, Roosevelt's theories on "race suicide" were grounded in the politics of white supremacy. Writing in the Black Scholar at the end of 1969, the historian and activist Nathan Wright argued that, in aiming to boost the numerical power of whites, TR's 
underlying goal was to deprive blacks of relative power. According to Wright, there was little difference between Hitler's crude form of genocide and the "low-keyed yet evident American theme that black men are a curse to the earth." ${ }^{75}$ Roosevelt, in this telling, was merely one of the more vocal exponents of a deep-seated urge of white men to deprive black men of their power.

American Indians' and African Americans' memories challenged the image of Roosevelt as a champion of social justice. These counter-memories were largely in line with the work of radical historians who questioned the degree to which Roosevelt's policies were progressive in the true sense of the word. In reality, few of Gabriel Kolko's 1963 observations regarding Roosevelt were original. In 1948, Richard Hofstadter had observed that Roosevelt relied on the advice of "representatives of industrial and financial capital," that he created "a hundred times more noise than accomplishment" in his war against the trusts, and that the Northern Securities prosecution was first and foremost a "brilliant stroke of publicity." Kolko deepened each of these themes to argue that Roosevelt's economic policies enabled the ascendancy of business interests in American public life. ${ }^{76}$ Kolko's interpretation was not original, but it resonated with New Leftists who were apt to question the moral and material foundations of "the system."

The Vietnam experience contributed to a new-found willingness to accept the limitations of American power. While conservative congressman protested the efforts of the Nixon, Ford, and finally Carter administrations to renegotiate the terms of Roosevelt's 1903 treaty with Panama, the mainstream press expressed empathy toward Panamanians, who viewed the canal as a "symbol of 'Yankee imperialism." "77 In the mid 1970s, contributors to the New York Times, Washington Post, and Chicago Tribune cited Roosevelt's boast that he "took the Canal Zone while Congress was still debating what to do" as an example of an imperious American attitude that needed to change. ${ }^{78}$ Similarly, the Democratic Senator Frank Church argued:

Teddy Roosevelt and the White Fleet and the Big Stick, those are days that related to a period of empire, when great nations did as they pleased, with little hindrance. Those memories have nothing whatever to do with the realities of $1978 .{ }^{79}$

Proponents of a revised treaty suggested that Roosevelt's "big stick" approach had belonged to a different era. With a degree of wishful thinking, they believed that those days had passed.

Critics on the left undermined the image of Roosevelt as a champion of social justice and promoter of American values abroad. They also contributed to a shift in TR's reputation as essentially benign. In the 1920s, Mencken had mixed his satire with expressions of warmth, testifying to the seductive exuberance of Roosevelt's character. Satirists in the 1970s were not so readily seduced. Over the course of his political career, Richard Nixon had drawn on memories of TR as the "man in the arena": following his defeat in the 1960 election, Nixon sent his supporters a letter that quoted from TR's speech; his 1968 campaign team ran a televised series of staged town-hall meetings that portrayed Nixon as the "man in the arena"; and he returned to the motif of the man who "fails while daring greatly" upon his resignation in $1974{ }^{80}$ For those predisposed to doubt Nixon's sincerity, these references served to plasticize and hollow out Roosevelt's words. In his 1972 play That Championship Season, the playwright Jason Miller assigned the "man in the arena" speech to Coach, a character who embodied trumped-up white masculinity. ${ }^{81}$ The New York Times columnist, William Safire, 
reflected that in Miller's hands, Roosevelt's notion of the "man in the arena" became "the ultimate alibi of a loser savaged by society." ${ }^{2}$ For the growing chorus of Nixon's detractors, Nixon's invocation of Roosevelt served only to degrade Roosevelt's reputation. While an earlier generation had laughed alongside Roosevelt as a bighearted, larger than life character, a more cynical generation laughed at him, as a symbol of their political leaders' pomposity and emptiness.

\section{The Search for a Hero} We paid for it! It's ours and we're gonna keep it!," Ronald Reagan demonstrated the political gains to be made through a robust defense of U.S. claims in Panama. While President Carter argued that, were he alive, Theodore Roosevelt would have supported the revised treaties, Congressman Philip Crane, the leader of the American Conservative Union, demurred. ${ }^{83}$ In a 1978 tract, the ultraconservative from Illinois argued that campus violence, Watergate, and defeat in Vietnam had placed the United States on the brink of collapse; the nation's communist enemies looked on with "wolfish eyes." Teddy Roosevelt, the man "whose leadership, more than anyone's, first won the United States a respected place as a major power," would have understood that there "must be no surrender in Panama," wrote Crane. ${ }^{84}$ Opinion polls from 1975 to 1978 indicated the American public's overwhelming opposition to the transfer of sovereignty of the Canal Zone to Panama. ${ }^{85}$ Although Carter gained the senatorial majority necessary to ratify the revised Panama Canal treaties, the New Right was the long-term political beneficiary of the debate, and its interpretation of history, rather than that of the liberal establishment, was persuasive to most Americans ${ }^{86}$

41 The New Left had framed their disgust with contemporary politicians in a broader critique of the establishment. But for many Americans, the political corruption of the 1970s fueled an intense nostalgia for a morally simpler past, as embodied by Roosevelt. The August 1979 cover of Newsweek featured a pastel-shaded TR, leading the charge up San Juan Hill, and the simple question: "Where Have All the Heroes Gone?" Within the pages of the magazine, Edmund Morris reflected:

Perhaps the ouster of Richard Nixon persuades us that our recent chief executives have represented the worst rather than the best in us, and we are wistful for the "essentially moral and essentially manly" qualities that the 26th President had in such abundance. ${ }^{87}$

Morris perpetuated a myth, which even Roosevelt's most complementary biographers discarded, that as a young boy TR had overcome his asthma through sheer force of will. 
He argued that, like the greatest heroes in history, Roosevelt had battled successfully against misfortune: he followed his father's body building program with "bulldog tenacity ... Fiber by fiber, his muscles tautened." 88 The sheer hyperbole of Morris's claims were evident when compared with the observations of David McCullough, an author hardly immune to Roosevelt-worship, who nonetheless noted in 1981 that Roosevelt's progress in building his body was "pathetic" and that his asthma never fully subsided. ${ }^{89}$ Morris's TR was Hercules and Leonidas combined, a "Homeric 'tamer of horses," with a "Praxitelian body."

Morris reinvigorated memories of Roosevelt as an intensely masculine leader to satisfy a popular yearning for an unapologetically American hero. For his efforts, he won the 1980 Pulitzer Prize and National Book Award. Morris's Theodore Roosevelt, much like the president-elect, Ronald Reagan, seemed to be the perfect antidote to the "national malaise" and "crisis of confidence" that had dominated the 1970s.

\section{The Feminists' TR}

In The Rise of Theodore Roosevelt and two subsequent volumes in his biographical trilogy, Morris was non-committal on TR's positions on race, and silent on issues of gender. ${ }^{91}$ Contesting this popular portrait of Roosevelt, feminist activists and scholars unpacked the racial and gendered dimensions of his policies. Women's historians in the early 1990s pointed to the institutional barriers faced by women during the Progressive Era despite, or even because of, Roosevelt's support for maternalist legislation, such as mother's pensions and workplace protection. ${ }^{92}$ Historians in the early 1990 s were drawn to an investigation of the origins of the maternalist state precisely because it was under attack. Reagan's budget reforms had led to major reductions in Aid to Families with Dependent Children; and conservative commentators argued that welfare was a cause of, rather than solution to, poverty. Recognizing a shift in public attitudes, Bill Clinton campaigned, and ultimately made good on, a pledge to "end welfare as we know it." ${ }^{93}$ Women's historians aimed to demonstrate that social welfare for women, initiated with President Roosevelt's blessing, was always more vulnerable to conservative attacks and rollback than social insurance for men.

In 1989, the feminist theorist Donna Haraway analyzed Roosevelt's looming image in the American Museum of Natural History as an expression of an explicitly white and male-dominated hierarchy-the "Teddy Bear Patriarchy." In Haraway's telling, Roosevelt and his elite friends embraced nature as a way of asserting their manhood. The taxidermal apes and "primitive" Africans displayed at the museum functioned as reference points for the white male body. ${ }^{94}$ Haraway's analysis anticipated a body of scholarship in the 1990s that exposed Roosevelt's whiteness and masculinity as social and political constructs. ${ }^{95}$ Feminist scholarship highlighted the limitations of the president's conceptions of a more just society, which never fully applied to women or people of color, and exposed white male power, as embodied by Roosevelt, as a careful construction rather than a natural given.

Well-received among like-minded academics, these studies did not prompt wholesale reassessments of Roosevelt's historical reputation. In 1948 and again in 1962, historians selected and polled by Arthur Schlesinger had ranked Theodore Roosevelt as the seventh greatest president. ${ }^{96}$ In 1996, those selected and polled by Schlesinger's son ranked TR as the sixth greatest president. ${ }^{97}$ If feminist historians' interpretations of 
Roosevelt made little impact on their colleagues, there was little hope that they would reach beyond academia, to the public at large. The feminist scholars' Roosevelt remained a self-contained counter-memory that ran parallel to, but rarely interfered with, long-standing memories of TR.

\section{Roosevelt in Recent Memory}

47 Among the various memories of Roosevelt sustained by left-of-center historians, the image of a champion of social justice has arguably been the only one to enter the mainstream of public history. While not devoid of scenes of battleground bravery, David Grubin's 1996 documentary TR suggested that Roosevelt displayed his true heroism in the political arena, fighting big business and battling for a "square deal" for the American people. ${ }^{98}$ Similarly, Douglas Brinkley, in his mammoth Wilderness Warrior, suggested that Roosevelt employed forceful executive leadership for liberal ends, resulting in the creation of five national parks, sixteen national monuments, and fiftythree wildlife reserves. Both Grubin's documentary and Brinkley's study belonged to the hagiographic school of Roosevelt historiography: $T R$ erased the brutal war in the Philippines from its narrative of the presidential years; Brinkley glossed over the long scholarly debate on the relative importance of conservation and preservation to TR, and did not acknowledge any contradictions between Roosevelt's love of hunting and his love of nature. ${ }^{99} \mathrm{~A}$ far more scholarly rendition of the TR-as-champion-of-socialjustice thesis was supplied by Kathleen Dalton in her 2004 biography. Dalton's overarching argument was that Roosevelt broke from the "iron cages" of Victorian thought, distanced himself from members of his class, and shattered his party's unity in order to achieve his vision of a more equitable democracy. ${ }^{100}$ For instance, Dalton pointed to shifts in Roosevelt's idea on race, as he became convinced that environment, rather than heredity, determined human capacity. ${ }^{101}$

Both Grubin's documentary and Dalton's magisterial study could be interpreted as "tacit but poignant" critiques of the direction of American politics in the 1990s and beyond, in which Republicans neglected his legacy of activist intervention on behalf of the public good, and Democrats moved from the center to the right. ${ }^{102}$ Dalton acknowledged:

Part of the challenge of writing about TR at the end of the twentieth century was to try to keep hidden my affectionate nostalgia about a liberal Republican who believed in the welfare state. ${ }^{103}$

In this effort, she was only partially successful. Dalton's Strenuous Life charted Roosevelt's growing commitment to social reform over the course of decades, implying that in maturity he realized the fullest expression of himself. ${ }^{104}$ As unalike in texture and tone as a television documentary and scholarly study are want to be, TR and Strenuous Life were similar in one regard: each aimed to revive memories of the progressive era as a time when a powerful political leader had dared to strive for a fairer nation.

Those on the right also drew upon familiar images of Theodore Roosevelt at the turn of the twenty-first century, albeit for entirely different ends. Neoconservative intellectuals revisited his foreign policy to produce an image of a warrior who never shied away from a good fight, and an assertive proponent of the United States' global leadership. Minimizing Roosevelt's efforts to mediate international disputes and avoid 
war with Japan, William Kristol and Robert Kagan argued that his foreign policy promoted a "robust brand of internationalism":

Roosevelt was an idealist of a different sort. He did not attempt to wish away the realities of power, but insisted that the defenders of civilization must exercise their power against civilization's opponents. "Warlike intervention by the civilized powers," he insisted, "would contribute directly to the peace of the world." 105

During the 2000 primary season, unimpressed by George W. Bush's seemingly modest vision for U.S. foreign policy, most neoconservatives backed John McCain's bid for the Republican nomination. ${ }^{106}$ In debate in Des Moines, McCain described TR as his "modern day role model and hero." Roosevelt, said McCain, "put the United States on the world's stage." ${ }^{107}$ But in the wake of 9/11, Bush was increasingly amenable to neoconservatives' strategic vision and embraced their interpretation of Roosevelt as an exemplary leader for extraordinary times. Bush described Edmund Morris' 2001 Theodore Rex as one of the best books he had read. ${ }^{108}$ The president would have found few cautionary tales regarding the perils of empire in Theodore Rex: Morris's passing references to the "fanatic Muslims" of Mindanao did not convey the human and moral costs of protracted guerilla warfare. ${ }^{109}$

Critics insisted that the neoconservatives had distorted TR's image: as the Philippines war dragged on, he had recognized the "folly" of American empire. ${ }^{110}$ But the neoconservative rendition of TR as an aggressive defender of American interests resonated with a broader public. A 2006 edition of Time magazine devoted to the Roosevelt presidency was indicative of why this TR appealed to the American imagination in the aftermath of $9 / 11$. The dominant theme of the issue, much like the dominant theme in Morris's biographies, was of Roosevelt as a man of gargantuan personal strength, overcoming illness, leading the charge up San Juan Hill, battling against corruption, and eluding death on the Amazon. The issue's cover story asserted that the twenty-sixth president "gave the nation a picture of itself as a place that could not fail to succeed, because it produced people who were vigorous and commandingpeople like Teddy Roosevelt." ${ }^{111}$ For a nation still reeling from existential threats, these heroic images of Roosevelt functioned as a reassurance of the resilience of the American spirit and the benignity of American power.

\section{Conclusion}

53 There is no single memory of Theodore Roosevelt; rather, various groups have remembered him through the prism of their intellectual and political predispositions and their current social conditions. Disillusioned and socially marginalized groups, and the scholars and intellectuals who aspire to speak for them, have always challenged the prevailing images of Roosevelt as a hard-boiled hero, a champion of social justice, and a well-meaning wag. Their counter-memories of Roosevelt as self-serving, aggressive, and governed by prejudice provide a cohesive critique of the twenty-sixth president. More profoundly, they represent a refusal to accept constructions of the United States as an exceptional nation, presided over by exceptional men.

Michael Kammen argues that the transmission of memory in the United States "tends to be decentralized, ad hoc, diffuse, and relatively non-coercive": the United States has no ministry of culture to police the boundaries of public memory. ${ }^{112}$ This "relatively non-coercive" cultural environment may help counter-memories to flourish within 
marginalized social groups, but it does not ensure that counter-memories expand beyond those who generate them, to undermine pre-existing tropes. The capacity of critics to shift the course of public memory is a function of their relative power in society, and those who have generated counter-memories of Roosevelt have usually lacked this fundamental power.

As most recently regenerated by the popular historian, Doris Kearns Goodwin, one element of TR's image produced by left-of-center historians has succeeded in entering the public imagination: that of a champion of social justice. Goodwin acknowledges that by portraying TR as a defender of the common man, she hopes to "guide readers ... toward a better understanding of what it takes to ... bring our country closer to its ancient ideals." ${ }^{113}$ But the net impact of the image of TR as a champion of social justice may run contrary to the intentions of historians who aim to reinvigorate the progressive era as an applicable episode from the United States' past. In 2002, the US historian Robert Johnston expressed his own preference for "hope over despair" in our understanding of progressive reforms. By "re-democratizing" the progressive era, Johnston suggested, historians could contribute to a living debate about the role that citizens could play in creating a more expansive and meaningful democracy. ${ }^{114}$ Images of TR battling the trusts and stumping for a Square Deal, as conjured in Grubin's TR, certainly represent a triumph of "hope over despair." But by de-coupling the carriage of progress from the engine of democratic process these same images risk encouraging complacency and passivity. Rather than portraying progressive social reform as the end product of deep commitments of citizen-activists, these images suggest that all that is required is a deus ex machina to nudge the United States towards a more perfect rendition of itself. Goodwin's, and especially Dalton's, understandings of the internal struggles of the progressive era are more complete. ${ }^{115}$ But despite these authors' sensitivities to the complex mechanisms of democracy, the most compelling figure in their narratives is, almost inevitably, the irrepressible TR. Images of Roosevelt as a champion of social justice thus risk eclipsing a much more realistic and usable history of social reform.

Some of the most recent renditions of Theodore Roosevelt in popular culture further demonstrate the resilience of familiar themes in public memories. In October 2012 the American Museum of Natural History reopened the Theodore Roosevelt Memorial Hall. The museum's tribute to Roosevelt was visually stunning and historically flat. The 1936 murals were restored to their former glory, but the curators offered no commentary that would enable the viewer to digest the images of Roosevelt as a product of their times. The murals celebrated TR as he had always been celebrated, as a hero, imperialist, and masculine archetype. ${ }^{116}$

57 Also in October 2012, Teddy's fortunes changed at the Nationals Park in Washington, D.C. For six seasons, a mascot version of Roosevelt had raced around the Nationals' stadium, always to fall short against his rivals, and fellow Mount Rushmore icons, Washington, Jefferson, and Lincoln. After a four-year-long, fan-based campaign to "Let Teddy Win," Roosevelt finally crossed the finishing line first during the Nationals' first ever playoff game, eliciting an explosion of joy in the stadium and Twittersphere. Teddy's long losing streak had endeared him to the fans, who embraced this latest iteration of Roosevelt as a benign friend. ${ }^{117}$

Theodore Roosevelt continues, too, to be a reference point for other presidents. In 2011, Barack Obama returned Osawatomie, Kansas, the site of Roosevelt's 1910 speech, 
to issue his own vision of a more progressive society. ${ }^{118}$ Most recently, in August 2017, Mike Pence, visiting the Panama Canal, compared Donald Trump to TR:

Then, as now, we have a builder of boundless optimism, who seeks to usher in a new era of shared prosperity all across this new world ... Just as President Roosevelt exhorted his fellow Americans to "dare to be great," President Donald Trump has dared our nation to "make America great again."119

These recent references demonstrate the ongoing salience of three TRs-a champion of progress, a benign figure, and a forceful hero-and are suggestive of a durability in how Americans imagine their political leaders. First, from Kennedy's narrow election victory over Nixon in 1960, to Bush Senior's trouncing of Dukakis in 1988, it is difficult to escape the conclusion that Americans demand that their leaders convey robust masculinity. Second, as evidenced by Reagan's successful election campaign in 1980, Americans look to their leaders to project an optimistic vision of their society as uniquely capable of progress. ${ }^{120}$ Finally, they want their president to be likeable, a man "you can have a beer with."121

As democratically elected leaders and highly visible figureheads, presidents are proxies for Americans' self-image. Hermann Hagedorn made this notion explicit in his immensely popular Boys' Life of Theodore Roosevelt. Roosevelt, wrote Hagedorn, was "the visible, individual expression of the American people":

He was the fulfiller of our good intentions ... He was human, he was our kind, and, being our kind, his successes and his fame were somehow our successes and our fame likewise. ${ }^{122}$

Almost one hundred years on, the same observations were implicit in Edmund Morris' final biography of Roosevelt. Without acknowledging Hagedorn's obvious influence on his source, Morris ended his work with the 1922 quotation of an Oyster Bay schoolboy: "He was a fulfiller of good intentions." 123 It seems that in recurring images of Theodore Roosevelt as robust, optimistic, and benign a great many Americans see themselves.

\section{NOTES}

1. Maurice Halbwachs, On Collective Memory, ed. and trans. Lewis A. Coser (Chicago: University of Chicago Press, 1992), 234.

2. Jan Vansina, Oral Tradition as History (Madison: University of Wisconsin Press, 1985), xii.

3. Barry Schwartz, "The Reconstruction of Abraham Lincoln" in Collective Remembering, eds. David Middleton and Derek Edwards (Newbury Park, CA: Sage, 1990), 82.

4. For "counter-memories," see Donald F. Bouchard, "Preface" in Michel Foucault, Language, Counter-Memory, Practice: Selected Essays and Interviews, ed. Bouchard and trans. Bouchard and Sherry Simon (Ithaca: Cornell University Press, 1977), 8-9.

5. On Roosevelt and historiography, see Richard H. Collin, "The Image of Theodore Roosevelt in American History and Thought, 1885-1965" (Ph.d. diss., New York University, 1966); John Gable, "The Man in the Arena of History: The Historiography of 
Theodore Roosevelt" in Theodore Roosevelt: Many-Sided American, eds. Natalie Naylor, Douglas Brinkley and John Gable (Interlaken, NY: Hearts of the Lakes, 1992), 613-643. On Roosevelt and film, see M. Patrick Cullinane, "The Memory of Theodore Roosevelt through Motion Pictures" in A Companion to Theodore Roosevelt, ed. Serge Ricard (Malden, MA: Wiley Blackwell, 2011), 502-520. On Roosevelt and foreign policy, see Andrew Johnston, “The Neoconservatives and Theodore Roosevelt" in L'Héritage de Theodore Roosevelt: Impérialisme et Progressisme, 1912-2012, ed.s Claire Delahaye and Serge Ricard (Paris: Harmattan, 2012), 155-174.

6. Edmund Morris, The Rise of Theodore Roosevelt (New York: Modern Library, 2001), 144.

7. Sarah Lyons Watts, Rough Rider in the White House: Theodore Roosevelt and the Politics of Desire (Chicago: University of Chicago Press, 2003), 126-135.

8. Kathleen Dalton, Theodore Roosevelt: A Strenuous Life (New York: Knopf, 2004), 97-102; Watts, Rough Rider, 127-130; Theodore Roosevelt, "Cross Country Riding in America," Century Magazine, July 1886. Roosevelt, “The Home Ranch," Century Magazine, March 1888.

9. David Greenberg, "Theodore Roosevelt and the Image of Presidential Activism," Social Research 78 (Winter 2011): 1066; Morris, Rise, 672.

10. Edmund Morris, Theodore Rex (New York: Random House, 2001), 117.

11. Greenberg, “Theodore Roosevelt," 1072.

12. Monica T. Albala, "Theodore Roosevelt: The Man and the Image in Popular Culture" in Theodore Roosevelt: Many-Sided American, 552-553. On hunting see, Douglas Brinkley, The Wilderness Warrior: Theodore Roosevelt and the Crusade for America (New York: Harper, 2009), 184, 236, 242, 506, 511, 544.

13. Dalton, Strenuous Life, 366.

14. Ibid., 372-413.

15. Mark Twain, "To the Person Sitting in Darkness," North American Review 172 (February 1901): 161-176.

16. William M. Gibson, Theodore Roosevelt Among the Humorists: W. D. Howells, Mark Twain, and Mr. Dooley (Knoxville: University of Tennessee Press, 1980), 13.

17. Dalton, Strenuous Life, 361.

18. Gerald L. Fetner, "The Washington Correspondent in the Progressive Era: The New York Times' Charles Willis Thompson," American Journalism 28 (Spring 2011): 23-47.

19. Thompson, “To Know Roosevelt was to Love Him," New York Times, January 7, 1919.

20. Thompson, "Theodore Roosevelt's Place in History," New York Times, January 6, 1929.

21. Kevin P. Murphy, Political Manhood: Red Bloods, Mollycoddles, and the Politics of Progressive Era Reform (New York: Columbia University Press, 2008), 178-187.

22. Thompson, “To Know Roosevelt."

23. Thompson, "Roosevelt's Place."

24. Ibid.

25. Dalton, Strenuous Life, 515-517.

26. Joseph Bucklin Bishop, Theodore Roosevelt and His Time Shown in His Own Letters (New York: Scribner's, 1920). 
27. Hermann Hagedorn, The Boys' Life of Theodore Roosevelt (New York: Harper, 1922), 3. For Hagedorn's impact, see: “Why I Admire Theodore Roosevelt," Washington Post, Junior Post, October 23, 1932; “Subject: 'T.R.," New York Times, November 3, 1957.

28. Godfrey Rathbone Benson Charnwood, Theodore Roosevelt (Boston: Atlantic Monthly Press, 1923), 3, 211.

29. Ibid., 21, 211.

30. Alan Havig, "Presidential Images, History, and Homage: Memorializing Theodore Roosevelt, 1919-1967," American Quarterly 30 (Fall 1978): 514-532, esp. 523.

31. "Coolidge Dedicates Mountain Memorial to Four Presidents," New York Times, August 11, 1927. Matthew Glass, “'Alexanders All': Symbols of Conquest and Resistance at Mount Rushmore" in American Sacred Space, ed.s David Chidester and Edward T. Linenthal (Bloomington: Indiana University Press, 1995), 167-178.

32. Nell Irvin Painter, Standing at Armageddon: The United States, 1877-1919 (New York: Norton, 1987), 355-380.

33. Lynn Dumenil, The Modern Temper: American Culture and Society in the 1920s (New York: Hill and Wang, 1995), 15-55.

34. H. L. Mencken "Roosevelt and Others," Smart Set, March 1920. Reprinted in H. L. Mencken, Prejudices: Second Series (New York: Knopf, 1920), 135.

35. Mencken, Prejudices, 112.

36. Henry F. Pringle, Theodore Roosevelt: A Biography (New York: Harcourt, Brace, 1931), 575.

37. Richard H. Collin, “Henry Pringle's Theodore Roosevelt: A Study in Historical Revisionism," New York History 52 (April 1971): 154.

38. John A. Garraty, The Nature of Biography (New York: Knopf, 1957), 137.

39. Pringle, Roosevelt, 347.

40. Mencken, Prejudices, 135.

41. Gable, "Arena of History," 616. Pringle, Roosevelt, 38, 247, 366, 429, 465-467.

42. Fred C. Hobson, Mencken: A Life (New York: Random House, 1994), 380.

43. James. L Golden, “FDR's Use of the Symbol of TR in the Formation of his Political Persona and Philosophy" in Theodore Roosevelt: Many-Sided American, 577-594. Eleanor Roosevelt was TR's niece.

44. "Roosevelt's View of the Big Job," New York Times, September 11, 1932.

45. "If Roosevelt Looks Back at Roosevelt," New York Times Magazine, October 22, 1933.

46. “If T.R. were in the White House Now," New York Times, January 19, 1936.

47. “The President's Speech at Theodore Roosevelt Memorial," New York Times, January 20, 1936.

48. William E. Leuchtenburg, Franklin D. Roosevelt and the New Deal, 1932-1940 (New York: Harper, 2009), 68-70, 301.

49. Albert Boime, "Patriarchy Fixed in Stone: Gutzon Borglum's Mount Rushmore," American Art 5 (Winter-Spring 1991): 152.

50. Rex Alan Smith, The Carving of Mount Rushmore (New York: Abbeville Press, 1985), 370. 
51. Boime, "Patriarchy," 161-162; Glass, “"Alexanders All," 168-169; Simon Schama, Landscape and Memory (New York: Knopf, 1995), 385-392.

52. William A. Mackay and A. A. Canfield, The Murals in the Theodore Roosevelt Memorial (New York: American Museum of Natural History, 1944).

53. “Unveils Statue of 'Rough Rider,"” New York Times, October 28, 1940.

54. "Statue of a Leader," New York Times, October 29, 1940.

55. John E. Bodnar, Remaking America: Public Memory, Commemoration, and Patriotism in the Twentieth Century (Princeton: Princeton University Press, 1992), 19.

56. Joseph Kesselring, Arsenic and Old Lace: A Comedy (New York: Random House, 1941), $21,80,89$.

57. Gable, “Arena of History," 618.

58. Elaine Tyler May, Homeward Bound: American Families in the Cold War Era (New York: Basic Books, 2008), 16-18, 138-141.

59. “Sagamore Hill Rounds Out First Tourist Year," New York Times, May 30, 1954.

60. "Fun and Games with a Famous Father," New York Times, August 15, 1954.

61. Hermann Hagedorn, The Roosevelt Family of Sagamore Hill (New York: Macmillan, 1954), 48-49, 83-84, 172-176, 250-251.

62. May, Homeward Bound, 138-141.

63. John Morton Blum, The Republican Roosevelt (Cambridge: Harvard University Press, 1954), 125-241; William Henry Harbaugh, Power and Responsibility; the Life and Times of Theodore Roosevelt (New York: Farrar, Straus and Cudahy, 1961), 270-285.

64. Harbaugh, Power and Responsibility, 522.

65. Arthur M. Schlesinger, The Vital Center: The Politics of Freedom (New Brunswick: Transaction, 1998), 21-24.

66. Kyle A. Cuordileone, “'Politics in an Age of Anxiety': Cold War Political Culture and the Crisis in American Masculinity, 1949-1960," Journal of American History 87 (September 2000): 544-545.

67. “Topics,” New York Times, January 12, 1961.

68. John F. Kennedy, "The Soft American," Sports Illustrated, December 26, 1960; Theodore Roosevelt, The Strenuous Life; Essays and Addresses (New York: Century, 1902), 1-21; Robert D. Dean, "Masculinity as Ideology: John F. Kennedy and the Domestic Politics of Foreign Policy," Diplomatic History 22 (January 1998): 46-47.

69. David Kennedy, Over Here: The First World War and American Society (New York: Oxford University Press, 1980), 148-149; Dean, “Masculinity," 31, 50-62.

70. “The $20^{\text {th }}$ Century Express" Time, July 3, 2006.

71. “Heroes: The Turning Point," Time, March 3, 1958.

72. "Six Indians Accused of Defacing Theodore Roosevelt Statue Here," New York Times, June 15, 1971.

73. Ibid.

74. Glass, “'Alexanders All,"” 174-775.

75. Nathan Wright, “Black Power v.s Black Genocide," Black Scholar 1 (December 1969): 49. 
76. Richard Hofstadter, The American Political Tradition and the Men Who Made It (New York: Knopf, 1948), 293-294. Compare with Gabriel Kolko, The Triumph of Conservatism; a Re-Interpretation of American History, 1900-1916 (New York: Free Press of Glencoe, 1963), 67, 72-77.

77. "Panama Canal in Brief," New York Times, February 8, 1974. Walter LaFeber, The Panama Canal: The Crisis in Historical Perspective (New York: Oxford University Press, 1989), 114.

78. "Panama Canal in Brief"; "The Truth Behind our Canal Caper," Chicago Tribune, April 24, 1976; "U.S. Created Panama, Setting the Stage for Stormy Relations," Washington Post, August 11, 1977.

79. Adam Clymer, Drawing the Line at the Big Ditch: The Panama Canal Treaties and the Rise of the Right (Lawrence: University of Kansas Press, 2008), 181-182.

80. "Man in the Arena," New York Times, June 7, 1973; Joe McGinniss, The Selling of the President, 1968 (New York, 1969), 67; "Nixon Resigns as $37^{\text {th }}$ President of the United States," Washington Post, August 9, 1974. Nixon also quoted from Roosevelt's diary in his farewell speech to White House Staff: "Sad, Emotional Nixon Bids Farewell to Staff," Washington Post, August 10, 1974.

81. Jason Miller, That Championship Season (New York: Atheneum, 1972).

82. "Man in the Arena," New York Times.

83. Michael J. Hogan, The Panama Canal in American Politics: Domestic Advocacy and the Evolution of Policy (Carbondale: Southern Illinois University Press, 1986), 149.

84. Philip M. Crane, Surrender in Panama: The Case Against the Treaty (New York: Dale Books, 1978), 16-17.

85. Ted J. Smith III and Michael J. Hogan, "Public Opinion and the Panama Canal Treaties of 1977," Public Opinion Quarterly 51 (Spring 1987): 5-30.

86. Hogan, Panama Canal, 114-131; Clymer, Drawing the Line.

87. Edmund Morris, "The Saga of Teddy," Newsweek, August 6, 1979.

88. Morris, Rise, 32-33.

89. David G. McCullough, Mornings on Horseback (New York: Simon and Schuster, 1981), 113, 367-368.

90. Morris, "Saga."

91. Morris, Rex, 224, 251, 258, 262.

92. Seth Koven and Sonya Michel, "Womanly Duties: Maternalist Politics and the Origins of Welfare States in France, Germany, Great Britain, and the United States, 1880-1920," American Historical Review 95 (October 1990): 1076-1108; Sonya Michel, “The Limits of Maternalism: Policies Toward Wage-Earning Mothers during the Progressive Era" in Mothers of a New World: Maternalist Politics and the Origins of Welfare States, eds. Seth Koven and Sonya Michel (New York: Routledge, 1993), 277-320; Linda Gordon, "Putting Children First: Women, Maternalism, and Welfare in the Early Twentieth Century" in U.S. History as Women's History: New Feminist Essays, eds. Linda K. Kerber, Alice Kessler-Harris and Kathryn Kish Sklar (Chapel Hill: University of North Carolina Press, 1995), 63-86.

93. John O'Connor, "US Social Welfare Policy: The Reagan Record and Legacy," Journal of Social Policy 27 (January 1998): 37-61. 
94. Donna Haraway, Primate Visions: Gender, Race, and Nature in the World of Modern Science (New York: Routledge, 1989), 26-58.

95. Arnaldo Testi, "The Gender of Reform Politics: Theodore Roosevelt and the Culture of Masculinity," Journal of American History 81 (March 1995): 1509-1533. Gail Bederman, Manliness \& Civilization: A Cultural History of Gender and Race in the United States, 1880-1917 (Chicago: University of Chicago Press, 1995), 170-215.

96. Arthur M. Schlesinger, "Historians Rate the U.S. Presidents," Life, November 1, 1948; Arthur M. Schlesinger, "Our Presidents: A Rating by 75 Historians," New York Times, July 29, 1962.

97. Arthur M. Schlesinger Jr., "Rating the Presidents: Washington to Clinton," Political Science Quarterly 112 (Summer 1997): 179-190.

98. David Grubin, TR (PBS Video, 1996).

99. Matthew Frye Jacobson, "Imperial Amnesia: Teddy Roosevelt, the Philippines, and the Modern Art of Forgetting," Radical History Review, 73 (Winter 1999): 117-127; Brinkley, Wilderness Warrior, 5, 19, 59.

100. Dalton, Strenuous Life, 44-5, 291-2, 295, 298.

101. Ibid., 126, 322. Dalton's owed this interpretation in large part to Thomas G. Dyer, Theodore Roosevelt and the Idea of Race (Baton Rouge: Louisiana State University Press, 1980), 17, 22-44.

102. Jacobson, "Imperial Amnesia," 124.

103. Kathleen Dalton, "Finding Theodore Roosevelt: A Personal and Political Story," Journal of the Gilded Age and Progressive Era 6 (October 2007): 374.

104. Dalton, Strenuous Life, 524.

105. Robert Kagan and William Kristol, "Introduction: National Interest and Global Responsibility" in Present Dangers: Crisis and Opportunity in American Foreign and Defense Policy, eds. Robert Kagan and William Kristol (San Francisco: Encounter, 2000), 23.

106. Adam Wolfson, "Conservatives and Neoconservatives" in the The Neocon Reader, ed. Irwin Stelzer (New York: Grove Press, 2004), 226.

107. John McCain III, Iowa Republican Presidential Primary Debate (Des Moines, Iowa, December 13, 1999). McCain also expressed his admiration for Roosevelt as a "reformer" and a "truly wonderful father and family man." See also M. Patrick Cullinane, "Invoking Teddy: The Inspiration of John McCain's Foreign Policy," Diplomacy and Statecraft, 19:4 (2008): 767-786.

108. George W. Bush, Decision Points (New York: Crown Publishers, 2010), 470.

109. Morris, Rex, 119, 457-458.

110. John B. Judis, The Folly of Empire: What George W. Bush Could Learn from Theodore Roosevelt and Woodrow Wilson (New York: Scribner, 2004).

111. " $20^{\text {th }}$ Century Express," Time.

112. Michael G. Kammen, Mystic Chords of Memory: The Transformation of Tradition in American Culture (New York: Knopf, 1991), 14.

113. Doris Kearns Goodwin, The Bully Pulpit: Theodore Roosevelt, William Howard Taft, and the Golden Age of Journalism (New York: Simon and Schuster, 2013), xiv. 
114. Robert D. Johnston, "Re-Democratizing the Progressive Era: The Politics of Progressive Era Political Historiography," Journal of the Gilded Age and Progressive Era 1 (January 2002): 68-92.

115. Goodwin, Bully Pulpit, xii, 323, 574; Dalton, Strenuous Life, 373-78.

116. "Bully! Museum Restores its Shrine to Roosevelt," New York Times, October 26, 2012.

117. “Teddy Wins First Presidents' Race” Washington Post, DC Sports Blog, October 3, 2012 (accessed August 25, 2013). “Twitter Reacts to Teddy's First Win," Washington Post, DC Sports Blog, October 3, 2012 (accessed August 25, 2013).

118. "In Kansas, a Combative Obama Tries on his Teddy Roosevelt Hat," Christian Science Monitor, December 6, 2011.

119. "Pence Compares Trump to Teddy Roosevelt, Praises his 'Can-Do Spirit," Chicago Tribune, August 17, 2017.

120. William E. Pemberton, Exit with Honor: The Life and Presidency of Ronald Reagan (Armonk: Sharpe, 1997), 89.

121. "Obama Seizes Chance to Score as an Everyman," New York Times, March 22, 2012.

122. Hagedorn, Boys' Life, 2-3.

123. Morris, Colonel Roosevelt (New York: Random House, 2010), 570.

\section{ABSTRACTS}

Following scholarship that suggests that societies crave continuity in their collective memories, this article identifies recurring themes in American memories of Theodore Roosevelt as an intensely masculine leader, a champion of social justice, and a loveable character. Memories of Roosevelt since his death have not been static. Leftist scholars and activists have contributed to counter-memories of TR as chauvinist, racist, and a dangerous imperialist. The interplay between memories and counter-memories of Theodore Roosevelt suggests that while cultural pluralism enables a multiplicity of memories to flourish within American society, it does not ensure that counter-memories expand beyond those who generate them. The resilience of memories of Roosevelt as a hero, champion, and friend is indicative of durable qualities in Americans' selfimage.

\section{INDEX}

Keywords: counter-memory; historiography; memory; politics of memory; popular history; presidential history; Theodore Roosevelt 